\title{
Cow-level association between serum 25-hydroxyvitamin D concentration and Mycobacterium avium subspecies paratuberculosis antibody seropositivity: A pilot study
}

\author{
U. S. Sorge, ${ }^{* 1}$ T. Molitor, ${ }^{*}$ J. Linn, $\dagger$ D. Gallaher, $\ddagger$ and S. W. Wells ${ }^{*}$ \\ *Department of Veterinary Population Medicine, \\ †Department of Animal Science, and \\ ‡Department of Food Science and Nutrition, University of Minnesota, St. Paul 55108
}

\begin{abstract}
Vitamin D deficiency has been associated with various human diseases. Therefore, the objective of this study was to evaluate the cow-level association between serum 25-hydroxyvitamin D $[25(\mathrm{OH}) \mathrm{D}]$ concentration and Mycobacterium avium ssp. paratuberculosis (MAP) seropositivity of dairy cows, adjusting for diet, breed, hair coat color, stage of lactation, reproductive status, and cow age. The sera of 80 MAP antibody ELISApositive and 80 test-negative herd mates from 5 Minnesota dairy herds were analyzed for $25(\mathrm{OH}) \mathrm{D}$ and 1,25-dihydroxyvitamin $\mathrm{D}\left[1,25(\mathrm{OH})_{2} \mathrm{D}\right]$. The cows' age, production records, and hair coat color were recorded. Additionally, feed samples were obtained and analyzed for vitamin $\mathrm{D}_{2}$ and vitamin $\mathrm{D}_{3}$ content. A linear mixed model was used to identify potential predictors for serum 25(OH)D concentration, accounting for herd of origin. The majority of rations analyzed had over 22,000 $\mathrm{IU}$ of vitamin D/day (maximum: 52,000 IU/d) and the study cows' average serum $25(\mathrm{OH}) \mathrm{D}$ concentration was $62.5 \pm 13.8 \mathrm{ng} / \mathrm{mL}$. Serum ELISA-positive cows had, on average, $5.3 \mathrm{ng} / \mathrm{mL}$ lower $25(\mathrm{OH}) \mathrm{D}$ serum levels than test-negative herd mates. The reproductive status of cows was also associated with the $25(\mathrm{OH}) \mathrm{D}$ levels, with fresh cows having the lowest serum concentration. In this cross-sectional study, a temporal or causal association between MAP antibody ELISA status and serum $25(\mathrm{OH}) \mathrm{D}$ concentration could not be evaluated. In addition, the high levels of vitamin $\mathrm{D}$ in the rations of participating farms and the average $25(\mathrm{OH}) \mathrm{D}$ serum concentration suggest that additional supplementation with vitamin $\mathrm{D}$ in the ration is likely to be ineffective. Key words: Johne's disease, vitamin D, paratuberculosis, cow
\end{abstract}

Received July 11, 2012.

Accepted October 31, 2012.

${ }^{1}$ Corresponding author: sorge@umn.edu

\section{INTRODUCTION}

Before the discovery of antibiotics, attempts to treat human tuberculosis included cod liver oil or sending ailing patients to warmer and sunnier climates for fresh air (Rhodes et al., 2003). Sunshine (UVB irradiation) and diet are important sources of vitamin $\mathrm{D}$ in both humans and mammals. Vitamin D has several forms. Vitamin $\mathrm{D}_{3}$ is produced by mammals in their skin (DiRosa et al., 2011). Vitamin $\mathrm{D}_{2}$ is produced by fungi growing on plant material (Jasinghe et al., 2007). Both vitamin $\mathrm{D}_{2}$ and vitamin $\mathrm{D}_{3}$ are also part of the diet and are subsequently utilized. In the liver, vitamin $\mathrm{D}$ is hydroxylated to 25 -hydroxyvitamin $\mathrm{D}[\mathbf{2 5}(\mathbf{O H})$ D]. In the kidney, $25(\mathrm{OH}) \mathrm{D}$ is again hydroxylated to 1,25-dihydroxyvitamin $\mathrm{D}\left[\mathbf{1 , 2 5}(\mathbf{O H})_{2} \mathrm{D}\right]$, which is the biologically active form of vitamin $\mathrm{D}$ and is considered a hormone. It plays an important role for bone metabolism and in the modulation of the immune response. For example, deficiency of $1,25(\mathrm{OH})_{2} \mathrm{D}$ has been associated with increased levels of proinflammatory cytokines (IL-6 and TNF- $\alpha$; Hayes et al., 2003; Di Rosa et al., 2011). These cytokines are part of the Th1-cell pathway, which is upregulated in patients with Crohn's disease. This multifactorial human disease is part of the inflammatory bowel diseases and is often compared with Johne's disease (JD) of ruminants, because of the similarities between the gross pathology of intestinal lesions of both diseases and because studies have identified an association between Mycobacterium avium ssp. paratuberculosis (MAP), the causative agent of JD, and Crohn's disease in some patients (Waddell et al., 2008). Interestingly, a north-south gradient has been described for the incidence of Crohn's disease, with a higher incidence in the northern areas that receive less sunshine (Loftus, 2004). Therefore, it was not unexpected that a recent study identified an association between low serum vitamin $\mathrm{D}$ levels and flare-ups in Crohn's disease patients (Ananthakrishnan et al., 2012) and that vitamin $\mathrm{D}$ supplementation was beneficial in reducing clinical signs of Crohn's disease in mice (Cantorna et al., 2000). In addition, a recent meta-analysis 
showed that humans with tuberculosis, another mycobacterial disease, had lower levels of vitamin $\mathrm{D}$ in serum compared with controls without tuberculosis (Nnoaham and Clarke, 2008). However, the direction of this association is unknown.

Paratuberculosis or JD is a chronic intestinal inflammation of ruminants and is manifested as diarrhea and wasting, resulting in reduced milk production and premature culling of affected cattle. The disease is not curable. In the United States, the percent of dairy operations with $\geq 5 \%$ of cull cows with clinical signs of JD varied regionally, with $10.1 \%$ in the Midwest, $7.1 \%$ in the Northeast, $0.1 \%$ in the West, and $2.7 \%$ in the Southeast (USDA, 2005). These data suggest that clinical JD is more common in cows living in areas receiving less sunshine - similar to the north-south gradient of Crohn's disease incidence. One could hypothesize this is due to reduced UVB exposure, resulting in insufficient vitamin $\mathrm{D}$ synthesis in cows living in the north and that a lack of sufficient vitamin D predisposes the cow to JD. Furthermore, studies by Goff et al. (1991, 1995) found that vitamin D receptor (VDR) concentration in the intestine decreases around calving and with age. Interestingly, cows are more likely to develop clinical JD shortly after calving and with increasing age. In addition, Jersey cows had lower levels of intestinal VDR than Holstein cows (Goff et al., 1995) and have been reported in one study to experience more clinical JD than cattle of other breeds (Cetinkaya et al., 1997). Although these observations are only circumstantial in evidence, they nonetheless point toward a potential association between vitamin D and JD. We hypothesized that MAP antibody-seropositive cows would have lower $25(\mathrm{OH}) \mathrm{D}$ levels than MAP-seronegative (presumed uninfected) cows. The objective of this study was to evaluate the cow-level association between serum 25(OH)D concentration and MAP seropositivity of dairy cows, adjusting for diet, breed, hair coat color, stage of lactation, reproductive status, and cow age.

\section{MATERIALS AND METHODS}

For the sample size calculation, 41 stored serum samples of dairy cows were analyzed for $25(\mathrm{OH}) \mathrm{D}$ to provide an appropriate estimate of an expected effect size. The sampled MAP-seropositive cows tended to have approximately $10 \mathrm{ng} / \mathrm{mL}$ lower serum 25(OH) D concentrations than ELISA-negative herd mates (Mann-Whitney U test, $P=0.09$ ). Based on this univariate analysis, a sample size of 80 seropositive and 80 seronegative cows was determined to show an expected serum $25(\mathrm{OH}) \mathrm{D}$ difference of $10 \mathrm{ng} / \mathrm{mL}$ (power: 0.80 ,

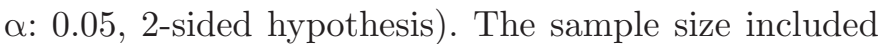
$20 \%$ additional cows for potential losses to follow-up.

For this study, 5 Minnesota dairy herds were included as study herds. Study herd selection criteria included Minnesota DHIA membership, milking more than 200 cows, and a historical within-herd prevalence of at least $5 \%$ (at previous herd tests with milk or serum ELISA). Furthermore, no pasture-based herds were included in the analysis to avoid the need to assess sunshine exposure or vitamin D intake through pasture. The herds were sampled at 2 time points in the summer of 2011: June/July and August. The sampling procedures were approved by the University of Minnesota's Animal Care Committee [Institutional Animal Care and Use Committee (IACUC) code no. 1105B99314].

\section{First Sampling}

The primary purpose of the first sampling in June/ July 2011 was to identify serum MAP antibody ELISApositive and antibody-negative cows. At sampling, two 10-mL serum Vacutainers (BD, Franklin Lakes, NJ) from at least 250 cows per herd were collected at the tail vein using $21 \mathrm{G} \times 1-1 / 4$-inch needles (BD Vacutainer Eclipse, blood collection needle; BD). The samples were immediately kept cool, stored at $4^{\circ} \mathrm{C}$ overnight, and the serum was collected the following day (centrifugation for $15 \mathrm{~min}$ at $3,000 \times g)$. Next, the serum was split into 3 aliquots and frozen at $-20^{\circ} \mathrm{C}$ in $2-\mathrm{mL}$ plastic tubes (micro tubes; Sarstedt AG \& Co., Nürnbrecht, Germany) until further analysis. One aliquot was submitted to the Minnesota Veterinary Diagnostic Laboratory to determine the serum MAP antibody ELISA status. From these, all 80 ELISA-positive cows were selected as well as 80 ELISA-negative cows that were fed the same ration and of similar age or lactation as test-positive cows.

In addition, a paper record of the feed rations as well as a sample of each ration fed was obtained from 4 herds from the day of sampling and the preceding day. From one herd (herd 1), only 1 sample of each ration was obtained. The representative samples were collected from 5 locations along the feed bunk right after delivery of the feed. The feed samples were frozen at $-20^{\circ} \mathrm{C}$ until further analysis. The samples were dried over $4 \mathrm{~d}$ at $60^{\circ} \mathrm{C}$ until no change in weight was observed. Then, they were ground and the 2 samples of each ration were mixed at equal proportions. The mixed feed samples were submitted to 2 laboratories for the analysis of their calcium, phosphorus, magnesium, potassium, sulfur, sodium, and chloride contents (Dairyland Laboratories Inc., Arcadia, WI), as well as 
vitamin $\mathrm{D}_{2}$ and $\mathrm{D}_{3}$ contents (Heartland Laboratories, Ames, IA; Hollis and Horst, 2007).

\section{Second Sampling}

Only the previously identified $80 \mathrm{MAP}$ antibody serum ELISA-positive and 80 negative control cows were targeted for further sample collection a month later. From each cow, two 10-mL blood samples (Vacutainer; BD) were collected via tail vein in August 2011. At the same herd visit, a fecal sample was also collected and immediately cooled. In addition, a standardized photograph was taken of the cow's back from approximately $1 \mathrm{~m}$ directly behind the cow. The pictures captured the same area of the backs of the cows (picture frame's lower border: roughly a hand width below the vulva/ middle of escutcheon; upper border: anterior to withers or headlocks) so that the coat color (ultimately recorded as percent black in 5\% increments) could be visually assessed over the same field.

The blood samples were processed as described above. The second blood sample and the fecal sample were submitted to the Veterinary Diagnostic Laboratory of the University of Minnesota (St. Paul) to be analyzed with the MAP antibody serum ELISA as well as fecal PCR and culture for MAP. Two grams of feces was used for bacterial culture of MAP and results were reported as 5 categories: negative; positive: 1 to 9,10 to 49,50 to 100 , or $>100$ colonies. However, for the purpose of this study, the MAP fecal culture results were also dichotomized to negative and positive. The frozen serum samples, from first and second sampling, of test-positive cows and their controls were analyzed for serum $25(\mathrm{OH}) \mathrm{D}$ and $1,25(\mathrm{OH})_{2} \mathrm{D}$ (Heartland Laboratories) and their mineral content, which included calcium, magnesium, phosphorus, chloride, potassium, and sodium (Animal Health Laboratories, Guelph, ON, Canada).

\section{Statistical Analysis}

The statistical procedures were conducted in SAS 9.2 (SAS Institute Inc., Cary, NC) and $\alpha=0.05$. The relationship between different serum vitamin $\mathrm{D}$ concentrations $\left[25(\mathrm{OH}) \mathrm{D}\right.$ and $\left.1,25(\mathrm{OH})_{2} \mathrm{D}\right]$ was assessed within cows and between sampling days using the Spearman correlation. The association between serum vitamin D levels and MAP fecal test results (MAP fecal culture and PCR) within and between sampling days was assessed with appropriate nonparametric univariable tests, including Spearman correlation, Kruskal-Wallis, and Mann-Whitney U test.

With the exception of hair coat color, the linear mixed model included only parameters that were collected at the first sampling (June/July). The model was built in multiple stages: first, a prescreening of univariable associations between $25(\mathrm{OH}) \mathrm{D}$ and predictor variables, including coat color (\% black), milk production [of the closest DHI test day or 305-d milk yield (lb)], percentage fat or percentage protein in milk, serum-mineral concentrations, age, and MAP antibody serum ELISA sample-to-positive $(\mathbf{S} / \mathbf{P})$ ratio, was performed using nonparametric Spearman correlation. The association between the cows' $25(\mathrm{OH}) \mathrm{D}$ or $1,25(\mathrm{OH})_{2} \mathrm{D}$ seroconcentration and MAP antibody serum ELISA status (positive vs. negative), reproductive status, or ration were investigated with Mann-Whitney-U or KruskalWallis tests. Collinearity between predictors included in the model was assessed with appropriate association statistics and ultimately, the factor perceived to be biologically more important was chosen to be included in the linear mixed model.

In the end, a linear mixed model with serum $25(\mathrm{OH})$ D concentration of the first sampling as outcome was fitted. Factors with a $P \leq 0.25$ in the prescreening of the variables were included in this model. The following predictors from the first sampling day were initially included: MAP antibody ELISA status (positive vs. negative), the reproduction status (fresh, open, do not breed, bred, pregnant, or dry), vitamin $\mathrm{D}_{2}$ and $\mathrm{D}_{3}$ concentration of the ration fed, milk production of DHI test day, age in months, percentage milk fat, DIM, and biologically plausible interaction terms such as milk production on test day $\times$ vitamin $\mathrm{D}$ concentration of feed, $\mathrm{DIM}^{2}$, percentage milk fat $\times$ vitamin $\mathrm{D}$ in feed, and DIM $\times$ reproduction status. Through backward elimination, only factors with $P \leq 0.05$ were retained in the model. Pairs of matched cows and herds were included as random factors in the analysis. Least squares means with $95 \%$ confidence limits were calculated for categorical variables. Cows with missing observations were removed from the analysis and residual plots visually assessed for homoscedasticity, normal distribution, and linearity to judge the fit of the model. After removal of a factor, it would be reentered into the model at a later stage, to confirm that $P<0.05$.

In addition, kappa statistics were used to measure the agreement between results of the different MAP tests from the same test day or between sampling days. To retain a 2-by-2 table, suspect cases at the second ELISA $(\mathrm{n}=3)$ as well the PCR procedure $(\mathrm{n}=3)$ were removed from this analysis.

\section{RESULTS}

Participating herds had between 3 and 32 MAP antibody ELISA-positive cows at the initial screening at the first sampling. A description of participating herds 
Table 1. Description of the study herds

\begin{tabular}{|c|c|c|c|c|c|}
\hline Item & \multicolumn{5}{|c|}{ Study herd } \\
\hline Herd size $^{1}$ & 317 & 325 & 361 & 710 & 399 \\
\hline No. of cows tested & 256 & 254 & 299 & 289 & 317 \\
\hline No. of test-positive cows & 16 & 10 & 3 & 34 & 17 \\
\hline Fecal culture $^{3}$ & 13 & 6 & 3 & 28 & 10 \\
\hline MAP seroprevalence ${ }^{2}(\%)$ & 6.3 & 3.9 & 1.0 & 11.8 & 5.4 \\
\hline
\end{tabular}

${ }^{1}$ Number of cows $\geq 24$ mo at the first herd visit.

${ }^{2}$ At the first sampling; MAP $=$ Mycobacterium avium ssp. paratuberculosis.

${ }^{3}$ Based on the fecal samples of the selected test-positive and test-negative cows at the second sampling.

is provided in Table 1. The presence of MAP infections in the participating herds was supported by positive MAP culture and direct PCR results of the fecal samples from individual cows. The predominant breed was Holstein. Only 1 Brown Swiss and 1 crossbred cow were part of the data set; they were removed from the modeling due to the lack of comparable control animals. Furthermore, 10 study cows had been removed from the herds between the first and second sampling and, therefore, no photo, fecal PCR, or culture results were obtained from those cows. They remained in the analysis because their serum samples and production records of the first sampling were available and, therefore, data were available for the linear regression analysis. Unless otherwise stated, the mean and standard deviation of continuous parameters are reported.

The agreement between the different MAP infection status tests (serum MAP antibody ELISA, fecal PCR, and MAP culture) within cows ranged between good (kappa: 0.65 for ELISA1 and culture) and very good (kappa $=0.81$ between ELISA1 and ELISA2). The agreement between fecal MAP PCR and MAP culture was good (kappa $=0.76)$.

The serum 25(OH)D concentration ranged between 13.4 and $88.9 \mathrm{ng} / \mathrm{mL}$ (mean $\pm \mathrm{SD}: 62.4 \pm 13.8 \mathrm{ng} /$ $\mathrm{mL}$ ) at the first test and 12.6 and $100.3 \mathrm{ng} / \mathrm{mL}$ (mean $\pm \mathrm{SD}: 59.75 \pm 16.7 \mathrm{ng} / \mathrm{mL}$ ) at the second test. The $25(\mathrm{OH}) \mathrm{D}$ concentration of each test within cows was positively correlated $(\mathrm{r}=0.23, P<0.01$; Figure 1$)$. The serum 1,25(OH)2D concentration ranged between 11.9 and $203.8 \mathrm{pg} / \mathrm{mL}$ (mean $\pm \mathrm{SD}: 50.85 \pm 26.7 \mathrm{pg} /$ $\mathrm{mL}$ ) and 8.25 and $335.75 \mathrm{pg} / \mathrm{mL}$ (mean \pm SD: $54.21 \pm$ $39.05 \mathrm{pg} / \mathrm{mL}$ ) at the first and second test, respectively. All of the serum vitamin D concentrations $[25(\mathrm{OH})$ $\mathrm{D}$ and $1,25(\mathrm{OH})_{2} \mathrm{D}$ of both test days] were positively correlated with each other within cows $(\mathrm{r}>0.17, P<$ $0.03)$.

\section{Feed Samples}

The farms fed between 4 and 6 different rations. All rations fed to study cows were TMR and were calculated to include at least $25,000 \mathrm{IU}$ of total vitamin $\mathrm{D} /$ cow per day (minimum: 25,000 IU/cow per day; maximum: $52,000 \mathrm{IU} /$ cow per day). The paper records did not list the amount of calculated vitamin $\mathrm{D}$ in the ration for farms 3 and 4 . Three to 5 rations were analyzed per farm, which were the rations actually fed to enrolled cows. A total of 21 mixed feed samples were analyzed for their vitamin $\mathrm{D}_{3}$ and $\mathrm{D}_{2}$ and total vitamin $\mathrm{D}$ contents.

The majority of rations provided well over 22,000 $\mathrm{IU} / \mathrm{d}$ (maximum: 52,000 IU/d). However, on farms 4 and 5, the far-off and close-up average rations were below 19,000 and $15,000 \mathrm{IU} / \mathrm{d}$ in total vitamin $\mathrm{D}$, respectively. The lowest daily intake of total vitamin D was in herd 3, where close-up cows were only fed an estimated 12,800 IU/d. The amount of vitamin D in the rations was not associated with the MAP antibody seroprevalence of the herds $(P>0.05)$.

\section{Univariate Analysis}

The S/P ratio of the first MAP antibody serum ELISA was negatively correlated with the serum $25(\mathrm{OH}) \mathrm{D}$ concentration from the same sampling day $(\mathrm{r}=-0.278$, $P=0.004)$. The $\mathrm{S} / \mathrm{P}$ ratio of the second ELISA was negatively associated with the $25(\mathrm{OH}) \mathrm{D}$ concentration of both sampling days $(\mathrm{r}<0.16, P<0.04)$. The second $1,25(\mathrm{OH})_{2} \mathrm{D}$ concentration was associated with the $\mathrm{S} / \mathrm{P}$ ratios of both the first and second ELISA $(\mathrm{r}<-0.16$, $P=0.05)$, but the first $1,25(\mathrm{OH})_{2} \mathrm{D}$ concentration was not associated with any ELISA S/P values $(P>0.5)$.

The cows' BCS $(P>0.3)$, age $(P>0.7), 305$-d milk yield $(P>0.11)$, and milk production on test day 


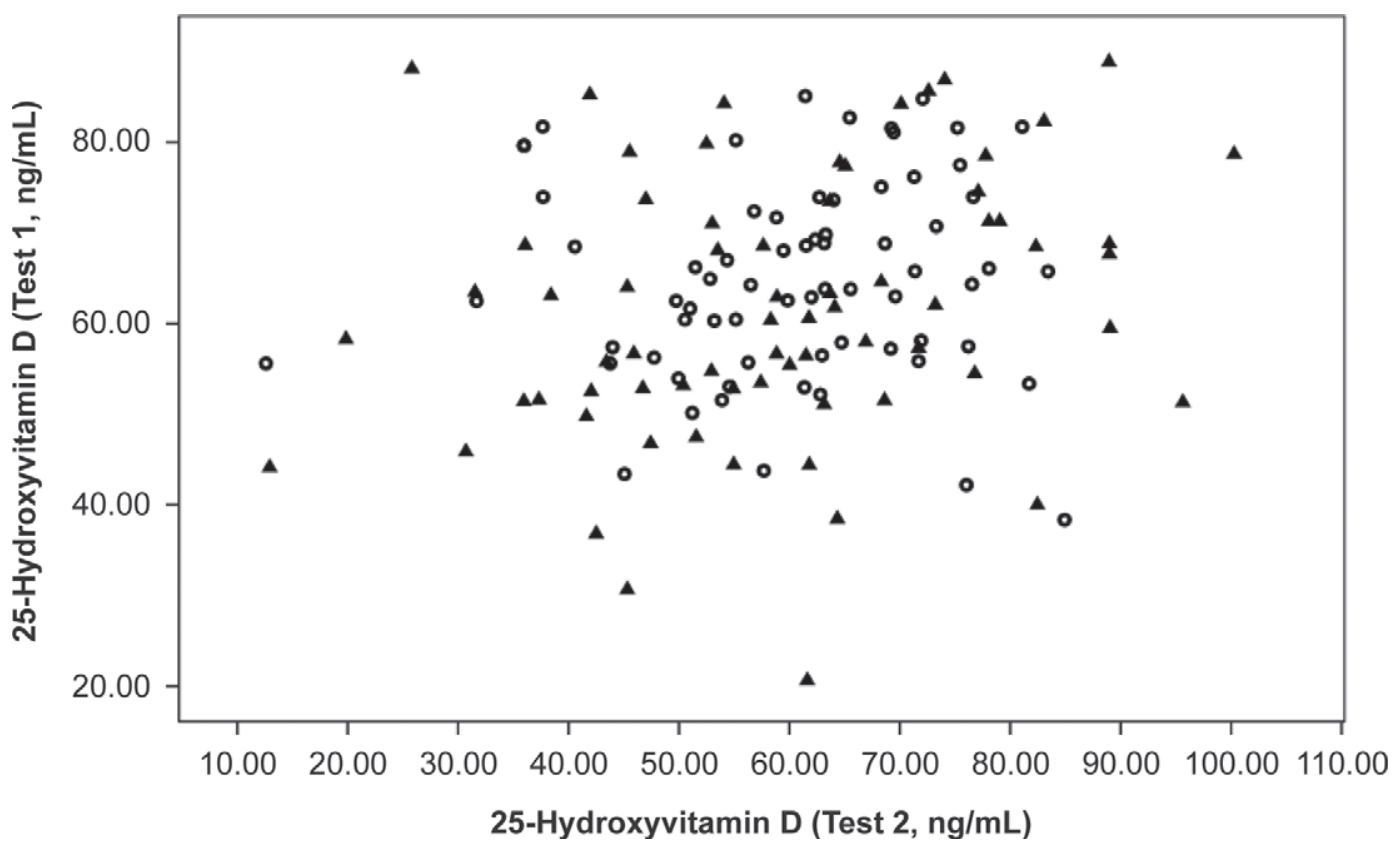

Figure 1. 25-Hydroxyvitamin $\mathrm{D}$ at first and second test in cows $(\mathrm{r}=0.26, P<0.01)$. Observations are depicted as Mycobacterium avium ssp. paratuberculosis (MAP) antibody ELISA-positive cows (triangle) and ELISA-negative cows (circle).

$(P>0.08)$ were not associated with the $1,25(\mathrm{OH}) 2 \mathrm{D}$ or $25(\mathrm{OH}) \mathrm{D}$ concentrations of either test day in the univariate analysis. Although the fecal PCR result for MAP was not associated with any of the vitamin D serum concentrations, the fecal MAP culture results (when left as 5 categories by colony count) were associated with both $25(\mathrm{OH}) \mathrm{D}$ concentrations $(P<0.04)$ and the second $1,25(\mathrm{OH})_{2} \mathrm{D}$ serum concentration $(P<$ $0.01)$. At the first test day, cows that were later MAP culture positive, had, on average, $60.7 \pm 14.1 \mathrm{ng} / \mathrm{dL}$ of $25(\mathrm{OH}) \mathrm{D}$ in their serum compared with $64.38 \pm 12.75$ $\mathrm{ng} / \mathrm{dL}$ of $25(\mathrm{OH}) \mathrm{D}$ in culture-negative cows $(P=0.09)$.

Serum calcium concentrations at the first test and reproductive status of the cow were associated $(P<$ $0.01)$. Because vitamin $\mathrm{D}$ regulates the serum calcium homeostasis (Plum and DeLuca, 2010), 25(OH)D could be considered a predictor of the serum calcium concentration rather than outcome. Therefore, we decided to include the stage of lactation or reproductive status instead of serum calcium concentration in the model. The serum $1,25(\mathrm{OH}) 2 \mathrm{D}$ concentration was also associated with the reproductive status of the cows $(P<0.01)$. Dry cows had the lowest $1,25(\mathrm{OH})_{2} \mathrm{D}$ concentration (mean \pm SD: $38.6 \pm 14.7 \mathrm{pg} / \mathrm{mL}$ ). Open cows had the highest mean $1,25(\mathrm{OH})_{2} \mathrm{D}$ concentration, whereas fresh $($ mean \pm SD: $53.8 \pm 19.2 \mathrm{pg} / \mathrm{mL})$, bred (mean \pm SD: $52.0 \pm 24.7 \mathrm{pg} / \mathrm{mL}$ ), and pregnant cows (mean $\pm \mathrm{SD}$ : $48.4 \pm 22.9 \mathrm{pg} / \mathrm{mL}$ ) had $1,25(\mathrm{OH})_{2} \mathrm{D}$ concentrations in between.

\section{Linear Mixed Model}

Two variables remained in the final model (Table 2). At the first sampling, cows that were MAP antibody ELISA positive had $5.3 \mathrm{ng} / \mathrm{mL}$ lower serum $25(\mathrm{OH}) \mathrm{D}$ concentrations than test-negative herd mates. Furthermore, the serum $25(\mathrm{OH}) \mathrm{D}$ levels were associated with the stage of lactation. Cows in mid lactation had the highest 25(OH)D levels, whereas dry and particularly fresh cows had the lowest $25(\mathrm{OH}) \mathrm{D}$ serum concentrations.

The serum 25(OH)D status of cows at the first sampling was not associated with either dichotomized fecal MAP culture (positive/negative) or fecal PCR results $(P>0.1)$ of the second test. However, when MAP culture results were included in the model as a categorical variable based on colony-forming units, differences in serum $25(\mathrm{OH}) \mathrm{D}$ concentration could be observed $(P=$ $0.0025)$. However, the relationship was not linear and heavily influenced by 5 cows with 50 to $100 \mathrm{cfu}$, which had significantly lower $25(\mathrm{OH}) \mathrm{D}$ serum levels than cows with other colony-forming-unit categories, including cows with $>100 \mathrm{cfu}(P<0.05)$. Other variables not associated with serum $25(\mathrm{OH}) \mathrm{D}$ in the model were the ration fed or the levels of vitamin $\mathrm{D}$ (vitamin $\mathrm{D}_{2}$ and vitamin $\left.\mathrm{D}_{3}\right)$ in the feed $(P>0.5)$. Likewise, the serum $1,25(\mathrm{OH})_{2} \mathrm{D}$ concentration was not associated with MAP antibody serum ELISA, fecal culture, or PCR status of the cows. 
Table 2. Association between Mycobacterium avium ssp. paratuberculosis (MAP) antibody serum ELISA status and 25-hydroxyvitamin-D (ng/ $\mathrm{mL}$ ) in dairy cows at the first sampling based on the results of the linear mixed model, which included herd and cow pairs as random effects

\begin{tabular}{|c|c|c|c|c|c|c|}
\hline Item & Estimate & SEM & $\frac{\text { LSM }}{\text { Average }^{1}}$ & \multicolumn{2}{|c|}{$95 \%$ CI } & $P$-value \\
\hline \multicolumn{7}{|l|}{ MAP antibody ELISA result } \\
\hline Negative & 5.34 & 2.11 & 64.47 & 57.4 & 71.6 & 0.013 \\
\hline Positive & Referent & & 59.13 & 52.0 & 66.25 & \\
\hline \multicolumn{7}{|l|}{ Reproductive status } \\
\hline Do not breed & 16.39 & 18.67 & 70.69 & 34.3 & 107.1 & 0.38 \\
\hline Open & 4.45 & 4.79 & 58.75 & 51.3 & 66.2 & 0.35 \\
\hline Pregnant & 8.91 & 6.65 & 63.21 & 58.9 & 67.5 & 0.02 \\
\hline Fresh & Referent & & 54.30 & 48.0 & 60.6 & \\
\hline
\end{tabular}

${ }^{1}$ Mean 25-hydroxyvitamin D concentration (ng/mL).

\section{DISCUSSION}

Besides its role in bone metabolism, vitamin D plays a pivotal role in the modulation of the immune system. An increasing number of studies have investigated the association between serum vitamin D levels and infectious and noninfectious diseases in the recent human medical literature (Plum and DeLuca, 2010). However, this association has not been previously evaluated for cattle and their MAP infection status.

The average serum $25(\mathrm{OH}) \mathrm{D}$ concentration of the study cows was higher than the average human serum $25(\mathrm{OH}) \mathrm{D}$ concentration in northern latitudes, which average below $30 \mathrm{ng} / \mathrm{dL}$, especially during the winter months (Gozdzik et al., 2010). Serum 25(OH)D levels of cows in this study were more reflective of the serum $25(\mathrm{OH}) \mathrm{D}$ concentrations reported for outdoor workers during the summer (Barger-Lux and Heaney, 2002) or for Hawaiian surfers (Hollis et al., 2007). The latter's $25(\mathrm{OH}) \mathrm{D}$ levels reached a plateau of around $65 \mathrm{ng} /$ $\mathrm{mL}$ (approximate maximum: $80 \mathrm{ng} / \mathrm{mL}$ ). Therefore, it seems that the cows in this study were abundantly supplemented with vitamin D in their feed. The NRC (2001) suggests a daily intake of at least 21,000 IU of vitamin $\mathrm{D} / \mathrm{d}$ for mature cows and of $25,000 \mathrm{IU} / \mathrm{d}$ for older transition cows. Some of the cows in this study were fed up to $52,000 \mathrm{IU} / \mathrm{d}$ without obvious signs of vitamin $\mathrm{D}$ toxicity. In contrast, recommendations for human vitamin $\mathrm{D}$ intake suggest daily vitamin $\mathrm{D}$ intake of 600 to $800 \mathrm{IU} / \mathrm{d}$ and no more than $4,000 \mathrm{IU} / \mathrm{d}$ to avoid toxicity (FNIC, 2010).

Interestingly, despite the high levels of alimentary vitamin D supplementation and serum concentrations, cows with positive serum MAP antibody ELISA had still significantly lower serum $25(\mathrm{OH})$ D levels than testnegative herd mates. In addition, the serum $25(\mathrm{OH}) \mathrm{D}$ levels were negatively correlated with the $\mathrm{S} / \mathrm{P}$ ratio of the ELISA. Considering that antibody levels increase as the disease progresses, it seems likely that serum $25(\mathrm{OH}) \mathrm{D}$ concentration might decrease as Johne's disease progresses (Chiodini, 1996). Reasons for this decrease cannot be answered with this cross-sectional study. It is possible that lower vitamin D levels could predispose to infection with MAP. Alternatively, one might speculate that in the later stages of Johne's disease less vitamin $\mathrm{D}$ is absorbed from the intestine, more $25(\mathrm{OH}) \mathrm{D}$ is used up to maintain adequate $1,25(\mathrm{OH})_{2} \mathrm{D}$ levels to modulate the exuberant immune response in the MAP infected gut, or a combination of both, which could lead to lower serum $25(\mathrm{OH}) \mathrm{D}$ concentration. A temporal study that begins during calfhood is needed to evaluate the directionality of this relationship.

Interestingly, the reproductive status of the cow was also associated with the cow's serum $25(\mathrm{OH}) \mathrm{D}$ concentration. The $25(\mathrm{OH}) \mathrm{D}$ levels of study cows showed a curvature over the lactation, with the highest $25(\mathrm{OH}) \mathrm{D}$ serum level during mid lactation (open and bred cows). The $25(\mathrm{OH}) \mathrm{D}$ serum levels then declined from pregnant and milking to dry cows. The lowest $25(\mathrm{OH}) \mathrm{D}$ levels were observed in fresh cows, indicating a close association of $25(\mathrm{OH}) \mathrm{D}$ levels with the pregnancy cycle and potentially hormonal profile of cows. One might argue that the negative calcium balance in early lactation increases the production of $1,25(\mathrm{OH})_{2} \mathrm{D}$ for which more of the $25(\mathrm{OH}) \mathrm{D}$ is utilized. This would cause a decrease in serum $25(\mathrm{OH}) \mathrm{D}$ concentration after calving. This argument could be supported by the observation that the $1,25(\mathrm{OH}) \mathrm{D}$ concentration of fresh cows was slightly higher than in dry cows. However, this cannot be the sole explanation, because open cows had both the highest $25(\mathrm{OH}) \mathrm{D}$ and highest $1,25(\mathrm{OH})_{2} \mathrm{D}$ concentrations. Therefore, one might look at the observations by Goff et al. (1991, 1995), who described that intestinal VDR density decreased at the end of lactation and during the dry period. This reduction could lead to lower 
serum 25(OH)D concentrations. Fittingly, this study measured the lowest $25(\mathrm{OH}) \mathrm{D}$ serum concentrations in early postpartum cows. Considering that cows usually develop clinical JD shortly after parturition (i.e., when they are fresh), the association with VDR density and serum 25(OH)D concentrations could be important for the development of clinical JD. In the human literature, VDR gene polymorphisms have been described for patients susceptible to Crohn's disease (Simmons et al., 2000; Naderi et al., 2008). Whether this might also be true for cows susceptible to MAP infections warrants further investigation.

Factors that were not associated with the $25(\mathrm{OH}) \mathrm{D}$ status of the cow included the vitamin $\mathrm{D}$ feed intake, blackness of the cow, as well as the fecal MAP culture and PCR status of the cows. Intake of vitamin D was probably not associated with MAP status because cows in this study were all consuming daily amounts above NRC requirements, with most cows consuming between one and a half and 2 times their requirement. Therefore, we observed also only a small, but statistically significant difference of $5 \mathrm{ng} / \mathrm{mL}$ between test-positive and test-negative cows. One might question the biological significance of this finding, yet it may be of interest, because the $25(\mathrm{OH}) \mathrm{D}$ levels were still lower in MAP antibody-positive cows, despite heavy dietary supplementation with vitamin $\mathrm{D}$. The $1,25(\mathrm{OH})_{2} \mathrm{D}$ concentration of the first test was not associated with the MAP infection status of the cows (serum ELISA or fecal direct tests). One might speculate that the serum reservoir of $25(\mathrm{OH}) \mathrm{D}$ was sufficiently high in the vast majority of study cows that the conversion to $1,25(\mathrm{OH})_{2} \mathrm{D}$ by the renal $1 \alpha$-hydroxylase could be at physiological levels, regardless of the MAP antibody ELISA status of the cow. However, we fully acknowledge that we do not have the data to support this argument.

The pigmentation of the cow, recorded as her percent blackness, was also not associated with the $25(\mathrm{OH}) \mathrm{D}$ concentration. This lack of association had also been described previously by other authors (Hymøller and Jensen, 2012). The pigmentation of the skin primarily influences the amount of vitamin $\mathrm{D}_{3}$ produced in the skin through direct sunshine exposure in humans (Hall et al., 2010). However, the cows of this study were housed indoors (as per study design) and had very limited if any access to direct sunshine exposure. Therefore, sunshine acquisition of vitamin $\mathrm{D}_{3}$ was not a factor in the cows' serum $25(\mathrm{OH}) \mathrm{D}$ levels.

Last, the MAP infection status of the cow, determined through direct fecal tests for MAP-PCR and culture - or her second ELISA result, were not consistently associated with the $25(\mathrm{OH}) \mathrm{D}$ or $1,25(\mathrm{OH})_{2} \mathrm{D}$ concentrations. Overall, the agreement between the test results was at least good, indicating that MAP was present on farm and in the study population. Still, these conflicting observations are unexpected and are difficult to explain. The most likely explanation is that the sampling schedule and loss of ELISA-positive cows might have influenced the results at the second sampling.

\section{CONCLUSIONS}

This study was initiated to investigate whether an association between MAP antibody ELISA status and serum $25(\mathrm{OH}) \mathrm{D}$ concentration of cows exists. Although cows had a high daily intake of vitamin $\mathrm{D}$ and high serum $25(\mathrm{OH}) \mathrm{D}$ concentrations, differences were found in $25(\mathrm{OH}) \mathrm{D}$ concentrations based on the cows' serum MAP antibody ELISA status and reproductive stage, indicating that vitamin D might indeed be associated with MAP infection susceptibility and development of clinical JD. However, a temporal or causal association could not be established with this cross-sectional study. In addition, the high levels of vitamin $\mathrm{D}$ in the rations of participating farms and of average $25(\mathrm{OH}) \mathrm{D}$ serum concentrations make additional supplementation with vitamin $\mathrm{D}$ in the ration likely ineffective.

\section{REFERENCES}

Ananthakrishnan, A. N., H. Khalili, L. M. Higuchi, Y. Bao, J. R. Korzenik, E. L. Giovannucci, J. M. Richter, C. S. Fuchs, and A. T. Chan. 2012. Higher predicted vitamin D status is associated with reduced risk of Crohn's disease. Gastroenterology 142:482-489.

Barger-Lux, M. J., and R. P. Heaney. 2002. Effects of above average summer sun exposure on serum 25-Hydroxyvitamin D and calcium absorption. J. Clin. Endocrinol. Metab. 87:4952-4956.

Cantorna, M. T., C. Munsick, C. Bemiss, and B. D. Mahon. 2000 1,25-Dihydroxycholecalciferol prevents and ameliorates symptoms of experimental murine inflammatory bowel disease. J. Nutr. 130:2648-2652.

Cetinkaya, B., H. M. Erdogan, and K. L. Morgan. 1997. Relationships between the presence of Johne's disease and farm and management factors in dairy cattle in England. Prev. Vet. Med. 32:253-266.

Chiodini, R. J. 1996. Immunology: Resistance to paratuberculosis. Vet. Clin. North Am. Food Anim. Pract. 12:313-343.

Di Rosa, M., M. Malaguarnera, F. Nicoletti, and L. Malaguarnera. 2011. Vitamin $\mathrm{D}_{3}$ : $\mathrm{A}$ helpful immuno-modulator. Immunology 134:123-139.

FNIC (Food and Nutrition Information Center). 2010. Dietary reference intakes (DRIs): Estimated average requirements. Accessed Mar. 7, 2012. http://www.iom.edu/Activities/Nutrition/ SummaryDRIs/ /media/Files/Activity\%20Files/Nutrition/ DRIs/5_Summary\%20Table\%20Tables\%201-4.pdf.

Goff, J. P., T. A. Reinhardt, and R. L. Horst. 1991. Enzymes and factors controlling vitamin D metabolism and action in normal and milk fever cows. J. Dairy Sci. 74:4022-4032.

Goff, J. P., T. A. Reinhardt, and R. L. Horst. 1995. Milk fever and dietary cation-anion balance effects on concentration of vitamin $\mathrm{D}$ receptor in tissue of periparturient dairy cows. J. Dairy Sci. 78:2388-2394.

Gozdzik, A., J. L. Barta, A. Weir, D. E. C. Cole, R. Vieth, S. J. Whiting, and E. J. Parra. 2010. Serum 25-hydroxyvitamin D concentrations fluctuate seasonally in young adults of diverse ancestry living in Toronto. J. Nutr. 140:2213-2220.

Hall, L. M., M. G. Kimlin, P. A. Aronov, B. D. Hammock, J. R. Slusser, L. R. Woodhouse, and C. B. Stephensen. 2010. Vitamin 
D intake needed to maintain target serum 25-hydroxyvitamin D concentrations in participants with low sun exposure and dark skin pigmentation is substantially higher than current recommendations. J. Nutr. 140:542-550.

Hayes, C. E., F. E. Nashold, K. M. Spach, and L. B. Pedersen. 2003. The immunological functions of the vitamin d endocrine system. Cell. Mol. Biol. 49:277-300.

Hollis, B. W., and R. L. Horst. 2007. The assessment of circulating $25(\mathrm{OH}) \mathrm{D}$ and $1,25(\mathrm{OH}) 2 \mathrm{D}$ : Where we are and where we are going. J. Steroid Biochem. Mol. Biol. 103:473-476.

Hollis, B. W., C. L. Wagner, M. K. Drezner, and N. C. Binkley. 2007. Circulating vitamin $\mathrm{D}_{3}$ and 25-hydroxyvitamin D in humans: $\mathrm{An}$ important tool to define adequate nutritional vitamin D status. J. Steroid Biochem. Mol. Biol. 103:631-634.

Hymøller, L., and S. K. Jensen. 2012. 25-Hydroxyvitamincholecalciferol status in plasma is linearly correlated to daily summer pasture time in cattle at $56^{\circ} \mathrm{N}$. Br. J. Nutr. 108:666-671.

Jasinghe, V. J., C. O. Perera, and S. S. Sablani. 2007. Kinetics of the conversion of ergosterol in edible mushrooms. J. Food Eng. 79:864-869.

Loftus, E. V. 2004. Clinical epidemiology of inflammatory bowel disease: Incidence, prevalence, and environmental influences. Gastroenterology 126:1504-1517.

Naderi, N., A. Farnood, M. Habibi, F. Derakhshan, H. Balaii, Z. Motahari, M. R. Agah, F. Firouzi, M. G. Rad, R. Aghazadeh, H.
Zojaji, and M. R. Zali. 2008. Association of vitamin D receptor gene polymorphisms in Iranian patients with inflammatory bowel disease. J. Gastroenterol. Hepatol. 23:1816-1822.

Nnoaham, K. E., and A. Clarke. 2008. Low serum vitamin D levels and tuberculosis: A systematic review and meta-analysis. Int. J. Epidemiol. 37:113-119.

NRC. 2001. Nutrient Requirements of Dairy Cattle. 7th ed. National Academy Press, Washington, DC.

Plum, L. A., and H. F. DeLuca. 2010. Vitamin D, disease and therapeutic opportunities. Nat. Rev. Drug Discov. 9:941-955.

Rhodes, S. G., L. A. Terry, J. Hope, R. G. Hewinson, and H. M. Vordermeier. 2003. 1,25-Dihydroxyvitamin $\mathrm{D}_{3}$ and development of tuberculosis in cattle. Clin. Diagn. Lab. Immunol. 10:1129-1135.

Simmons, J. D., C. Mullighan, K. I. Welsh, and D. P. Jewell. 2000. Vitamin D receptor gene polymorphism: Association with Crohn's disease susceptibility. Gut 47:211-214.

USDA (US Department of Agriculture). 2005. Johne's disease on U.S. dairy operations, 2002. No. N427.0205. USDA:Animal and Plant Health Inspection Service:Veterinary Services:Centers for Epidemiology and Animal Health (USDA:APHIS:VS:CEAH), National Animal Health Monitoring System, Fort Collins, CO.

Waddell, L. A., A. Rajić, J. Sargeant, J. Harris, R. Amezcua, L. Downey, S. Read, and S. A. McEwen. 2008. The zoonotic potential of Mycobacterium avium spp. paratuberculosis: A systematic review. Can. J. Public Health 99:145-155. 